REGARDS

SUR LECONOMIE ALLEMANDE

BULLETIN ECONOMIQUE DU CRAC

\section{Regards sur l'économie allemande}

Bulletin économique du CIRAC

115 | 2014

Varia

\title{
Management interculturel
}

\section{(2) OpenEdition}

1 Journals

Édition électronique

URL : http://journals.openedition.org/rea/4781

DOI : 10.4000/rea.4781

ISSN : 1965-0787

Éditeur

CIRAC

\section{Édition imprimée}

Date de publication : 1 décembre 2014

Pagination : 39

ISSN : 1156-8992

\section{Référence électronique}

"Management interculturel », Regards sur l'économie allemande [En ligne], 115 | décembre 2014, mis en ligne le 01 décembre 2014, consulté le 22 septembre 2020. URL : http://journals.openedition.org/rea/ 4781 ; DOI : https://doi.org/10.4000/rea.4781

Ce document a été généré automatiquement le 22 septembre 2020.

(c) CIRAC 


\section{Management interculturel}

\section{RÉFÉRENCE}

ENGELEN Andreas, THOLEN Eva, Interkulturelles Management, Schäffer-Poeschel, Stuttgart, 2014, $310 \mathrm{p}$.

1 Ce manuel a vocation à rendre intelligible le management interculturel, dont le rôle a gagné en importance ces dernières années dans l'apprentissage de la gestion des entreprises. Au sein de multinationales en effet, il semble désormais indispensable d'identifier l'influence des cultures respectives sur les pratiques de management afin d'anticiper et de résoudre les possibles interrogations et problèmes que leur coexistence peut susciter. L'approche didactique est efficace : chaque grand chapitre est introduit par quelques questions qui trouvent leur réponse dans des conclusions intermédiaires. (Solène Hazouard) 